\title{
AVALIAÇÃO INTEGRADA DOS RECURSOS DE ÁGUAS SUBTERRÂNEAS E SUPERFICIAIS DA BACIA DO RIO BOQUEIRÃO, A OESTE DE TOUROS, RN
}

\author{
INTEGRATED EVALUATION OF SURFICIAL AND GROUND WATER RESOURCES \\ WITHIN BOQUEIRÃO RIVER BASIN, WEST OF TOUROS, RN
}

\author{
José Geraldo de Melo; Josimar Alves de Oliveira²; Vera Lúcia Lopes²; José Braz Diniz. Filho; \\ Mickaelon Belchior Vasconcelos ${ }^{1}$ e Fábio Henrique Roque da Silva ${ }^{1}$
}

\begin{abstract}
Recebido em:26/05/2005, aceito em: 18/04/2006
RESUMO A bacia hidrográfica do rio Boqueirão está situada na zona de transição entre a Bacia Sedimentar Costeira, onde o clima é úmido, e a Bacia Potiguar, região semi-árida, no Rio Grande do Norte. As águas subterrâneas armazenadas nos arenitos do Grupo Barreiras e a lagoa do Boqueirão constituem os mananciais utilizados para o suprimento das comunidades locais e de irrigação. Este trabalho foi realizado diante da perspectiva de aumentar a oferta de água para o atendimento de demandas locais e de comunidades da região semi-árida localizadas à distâncias de até $70 \mathrm{~km}$ do Boqueirão, onde águas são escassas. Verificou-se a possibilidade de captação de um volume de água de 17,8 milhões de $\mathrm{m}^{3} /$ ano, sendo que pouco mais de 50\% deste volume já é explotado atualmente. As águas subterrâneas no setor a leste da Lagoa do Boqueirão são de salinidade muito baixa e do tipo $\mathrm{Na}^{+}-\mathrm{Cl}^{-}$, enquanto que as águas nos demais setores são de salinidade média a elevada e do tipo $\mathrm{Ca}^{2+}-\mathrm{Mg}^{2+}-\mathrm{Cl}^{-}-\mathrm{HCO}_{3}^{-}$, provavelmente afetadas pelas águas de calcários e dolomitos subjacentes ao Aquífero Barreiras. As águas superficiais são de salinidade baixa a média e do tipo $\mathrm{Na}^{+}-\mathrm{Ca}^{2+}-\mathrm{Mg}^{2+}-\mathrm{Cl}^{-}-\mathrm{HCO}_{3}$, que provavelmente representam uma mistura de águas dos arenitos do Aqüífero Barreiras e das rochas carbonáticas.
\end{abstract}

Palavras chave: semi-árido, suprimento hídrico, água subterrânea, água superficial, qualidade de água.

\begin{abstract}
Boqueirão watershed is situated in the transition zone between the Coastal Basin, where the climate is humid, and, the Potiguar Basin, semi-arid region, Rio Grande do Norte State, covering $190 \mathrm{~km}^{2}$. The Barreiras aquifer and the Boqueirão Lake are the sources that supply the communities and irrigate part of that area. This work evaluates the possibilities of increasing the water provision to the local development and to supplying communities in the semi-arid region placed up to $70 \mathrm{~km}$ from the Boqueirão, where there is a shortage of water. An annual exploitable volume of water of about 17.8 million $\mathrm{m}^{3}$ was estimated. The groundwater on the East sector of the Boqueirão Lake has a very low salinity average, and $\mathrm{Na}^{+}-\mathrm{Cl}^{-}$is the water type that predominates. On the other sectors, the salinity of water varies from medium to high and are $\mathrm{Ca}^{2+}-\mathrm{Mg}^{2+}-\mathrm{Cl}^{-}-\mathrm{HCO}_{3}$ water type. In this case, it is likely that the limestone rocks underlying the Barreiras Aquifer affect the waters. The salinity of the surface waters varies from low to medium and are $\mathrm{Na}^{+}-\mathrm{Ca}^{2+}-\mathrm{Mg}^{2+}-\mathrm{Cl}^{-}-\mathrm{HCO}_{3}$, which might indicate a mixture of waters from the Barreiras Aquifer sandstone and the carbonate rocks.
\end{abstract}

Keywords: semi-arid, water supply, groundwater, surface water, water quality.

\section{INTRODUÇÃO}

A área de estudo localiza-se a cerca de 10 $\mathrm{km}$ a oeste da cidade de Touros (RN), e corresponde aos cursos superior e médio do rio Boqueirão, cuja superfície é da ordem de 190 $\mathrm{km}^{2}$ (Figura 1). Está situada na zona de transição entre o litoral leste do Estado, que se caracteriza por vales úmidos e rios perenes, e o litoral norte, tipicamente semi-árido e em geral com rios transitórios. As águas subterrâneas e a Lagoa do Boqueirão constituem os principais recursos utilizados pela população, tanto no abastecimento humano como na irrigação. O objetivo deste trabalho foi verificar as possibilidades de se ampliar a oferta de água para o atendimento não somente de demandas locais como também no suprimento de comunidades da região semi-árida da Bacia Potiguar, situadas à distâncias de até 70 $\mathrm{km}$ da área de estudo, onde os recursos hídricos superficiais e subterrâneos são escassos.
Inicialmente, foi realizado um cadastramento das estruturas hídricas e dos usuários das águas subterrâneas e da lagoa, que permitiu conhecer as características dos poços existentes e estimar o volume anual de água explotado. A estrutura hidrogeológica foi definida com base na correlação litoestratigráfica de perfis poços cadastrados e em resultados de novas perfurações. Estas incluem poços e piezômetros para monitoramento dos níveis potenciométricos e para a realização de testes de aquífero que permitiram conhecer os parâmetros hidrodinâmicos do Aqüífero Barreiras. Com base nos dados de profundidade dos níveis da água subterrânea e de nivelamento dos poços foi definido o padrão da superfície potenciométrica e características do fluxo subterrâneo. A capacidade de acumulação de água da lagoa do Boqueirão foi obtida através de levantamento topo-batimétrico.

\footnotetext{
${ }^{1}$ UFRN/ Depto de Geologia/PPGEO (jgmelo@ufrnet.br), (mickvasconcelos@yahoo.com.br)

${ }^{2}$ SERHID - Secretaria de Recursos Hídricos do Estado do Rio Grande do Norte
} 
A caracterização hidroquímica e a qualidade das águas são apresentadas com base na interpretação dos resultados de análises químicas de amostras de água de poços e das águas superficiais. Foram analisados os cátions principais (sódio, potássio, cálcio e magnésio), os ânions principais (cloreto, sulfato, carbonato e bicarbonato) e os compostos da série nitrogenada (amônio, nitrito e nitrato), além do potássio, ferro, condutividade, $\mathrm{pH}$ e sólidos totais dissolvidos.

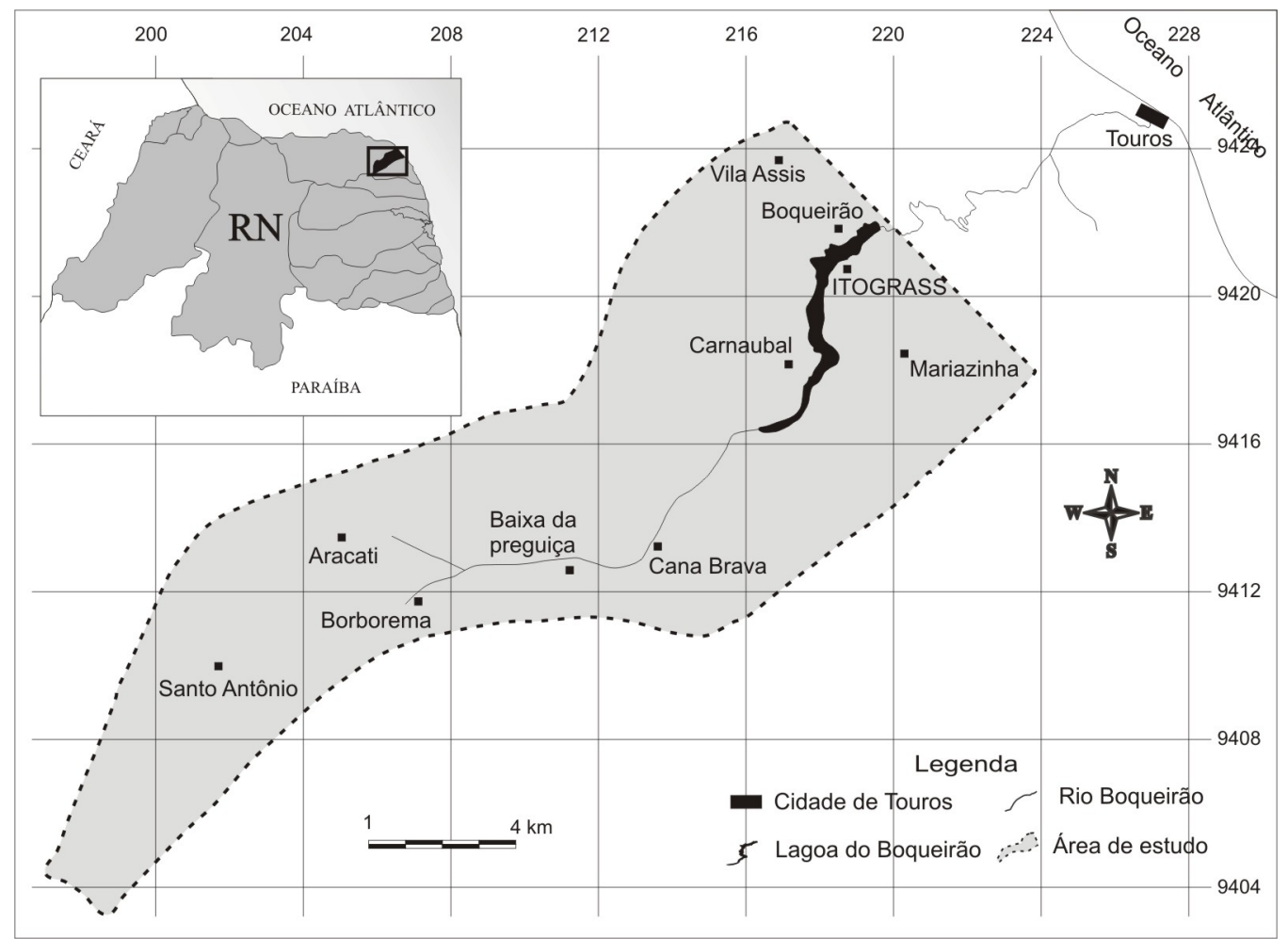

Figura 1 - Mapa de localização da área Figure 1 - Area location map

\section{FATORES FÍSICOS}

A área é caracterizada por um clima tropical chuvoso, do tipo úmido seco a sub-úmido, com precipitações pluviométricas anuais da ordem de $792 \mathrm{~mm}$. Está situada na bacia hidrográfica do rio Boqueirão, sendo cortada por este no sentido SW-NE, tendo como principal característica a formação da lagoa do Boqueirão, cujas águas são parcialmente drenadas em superfície pelo curso do rio a jusante da lagoa e em seguida descarregada no mar. Fora do domínio do curso de água superficial, a rede de drenagem é muito pouco densa, sugerindo reduzidos escoamentos superficiais e elevadas taxas de infiltração.

Do ponto de vista geomorfológico, a maior parte da bacia faz parte da unidade geomorfológica dos Tabuleiros Costeiros, que nesta região são pouco dissecados, apresentando extensas superfícies com relevos planos a suavemente inclinados, cujas altitudes variam desde $12 \mathrm{~m}$, à margem da lagoa do Boqueirão, até $133 \mathrm{~m}$ no alto curso da bacia.

A área é formada por sedimentos tércioquaternários do Grupo Barreiras, recobertos por sedimentos recentes representados por dunas e aluviões (Figura 2). O Grupo Barreiras é constituído de arenitos heterogêneos, em geral pouco consolidados, e argilas variegadas intercaladas. $\mathrm{Na}$ parte superior dos perfis, os sedimentos são mais argilosos e na parte inferior, são em geral mais arenosos, com granulometria variando de média a grossa. O Grupo Barreiras sobrepõe-se às rochas carbonáticas de idade atribuída ao Cretáceo, que são calcários, calcarenitos e dolomitos da Formação Jandaíra, aflorantes no setor noroeste da área já fora dos limites desta. Do ponto de vista estrutural, a área está situada na região de influência do denominado "Alto de Touros", com a ocorrência de falhamentos escalonados na direção de montante para jusante da bacia. 


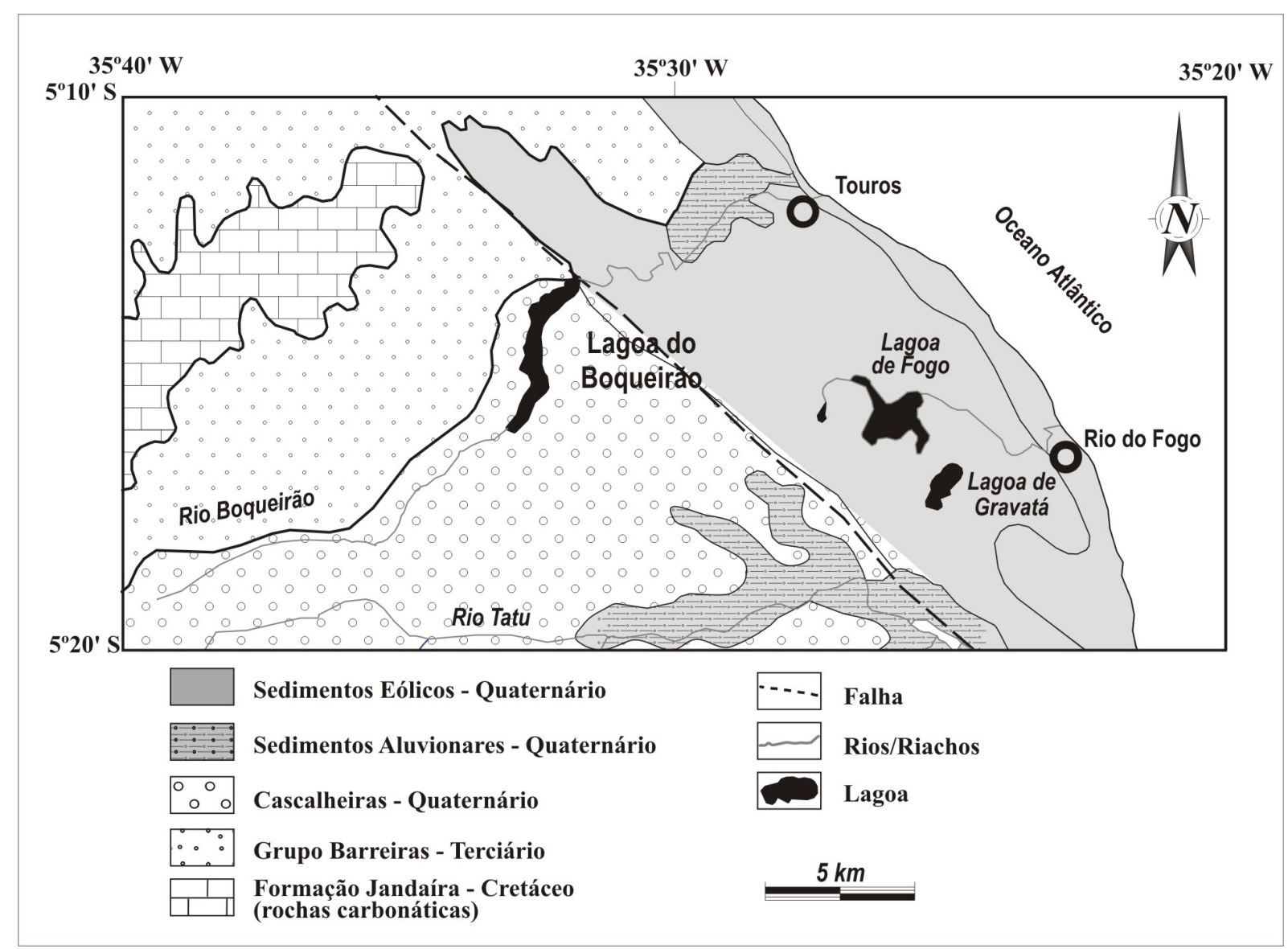

Figura 2 - Geologia regional (Modificado de Mont'Alverne, 1998)

Figure 2 - Regional Geology (Modified from Mont'Alverne, 1998)

\section{RECURSOS HÍDRICOS SUBTERRÂNEOS}

\section{Uso das águas subterrâneas}

De acordo com os resultados do cadastramento (janeiro 2001), na área de estudo existem 36 poços tubulares e 15 poços escavados (cacimbões) captando águas subterrâneas (Figura 03), que no total fornecem descarga anual da ordem de 2 milhões de $\mathrm{m}^{3}$. Essas águas são utilizadas na irrigação de culturas e no suprimento doméstico das comunidades e população rural em geral. Os poços tubulares apresentam profundidades que variam de 10 a $256 \mathrm{~m}$, na maior parte dos casos captando águas armazenadas nos sedimentos inferiores do Grupo Barreiras com descargas muito variadas, desde vazões pouco significantes com menos de $5 \mathrm{~m}^{3} / \mathrm{h}$ até vazões de $110 \mathrm{~m}^{3} / \mathrm{h}$.
Os poços que captam águas dos calcários, subjacentes ao Barreiras (profundidade superior a $85,0 \mathrm{~m}$ ), em geral fornecem baixas vazões

\section{Estrutura hidrogeológica}

De acordo com os resultados das sondagens mecânicas, os sedimentos Barreiras desenvolvem espessuras que variam de $37 \mathrm{~m}$ até $84 \mathrm{~m}$. No alto curso da bacia hidrográfica do rio Boqueirão esses sedimentos são insaturados (Aracati e Santo Antônio) e no médio curso, na altura da lagoa do Boqueirão, desenvolvem espessuras saturadas efetivas (excluídas as argilas) que atingem $47 \mathrm{~m}$ na Vila Assis (Tabela 1). De modo geral, há um aumento das espessuras, tanto totais como saturadas, de montante para jusante. 


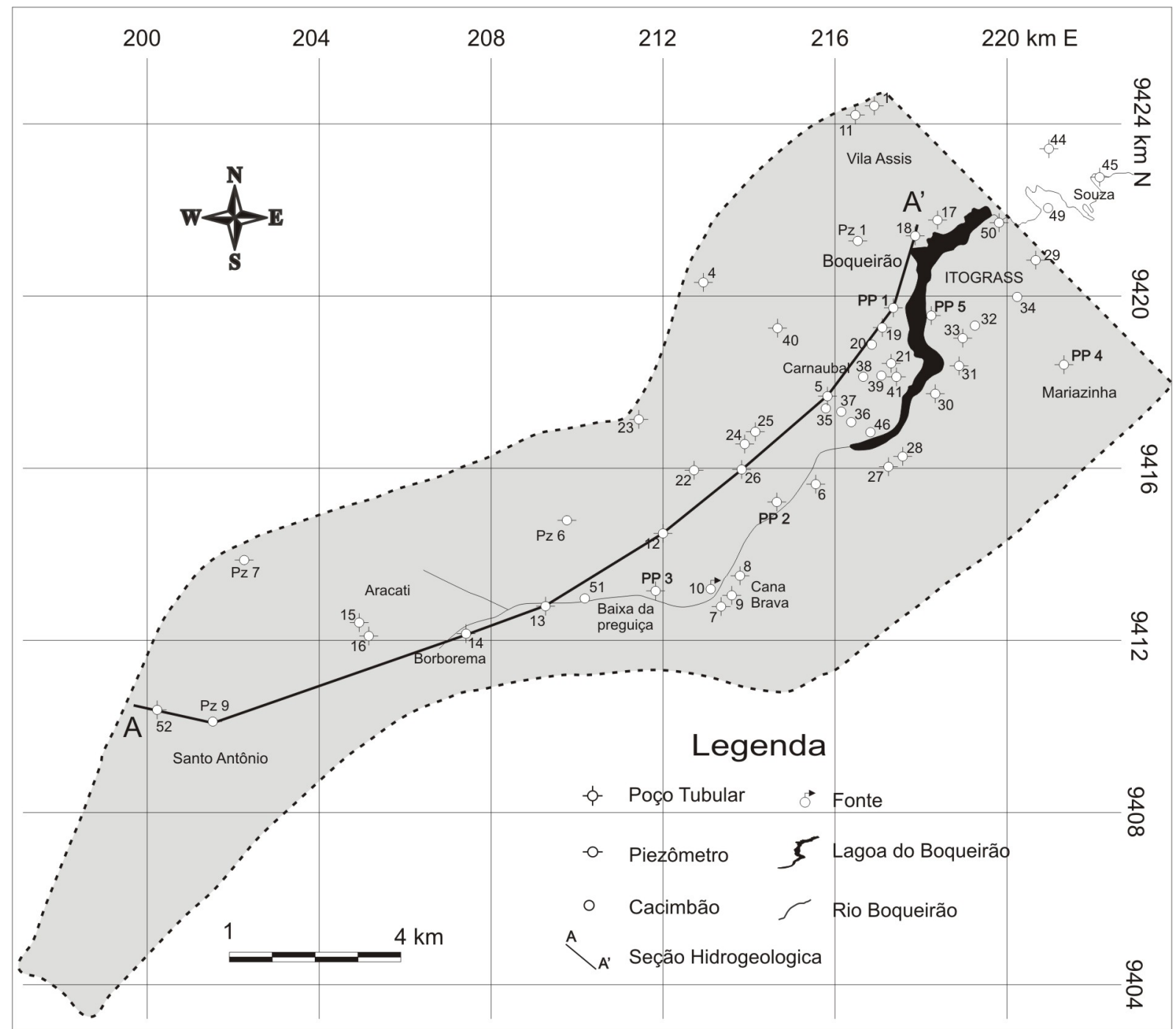

Figura 3-Mapa de localização dos poços cadastrados e da seção hidrogeológica AA' Figure 3-Wells and hydrogeological section AA' location

Tabela 1-Espessuras do Aqüífero Barreiras

Table 1 - Barreiras Aquifer thickness

\begin{tabular}{cccccc}
\hline $\begin{array}{c}\text { Poço/ } \\
\text { Piezômetro }\end{array}$ & Localização & $\begin{array}{c}\text { Profundidade do } \\
\text { poço }(\mathbf{m})\end{array}$ & $\begin{array}{c}\text { Nível estático } \\
(\mathbf{m})\end{array}$ & $\begin{array}{c}\text { Espessura } \\
\text { total(m) }\end{array}$ & $\begin{array}{c}\text { Espessura } \\
\text { saturada } \\
\text { efetiva(m)* }\end{array}$ \\
\hline PZ-1 & Vila Assis & 85,00 & 33,10 & 84,00 & 46.9 \\
PP-1 & Boqueirão & 58,00 & 1,07 & 56,00 & 26,00 \\
PZ-2 & Boqueirão & 55,00 & 0,63 & 53,00 & 24,00 \\
PZ-3 & Boqueirão & 17,00 & 0,78 & - & - \\
PP-2 & Cana-Brava & 62,00 & 32,42 & 61,00 & 27,00 \\
PZ-4 & Cana-Brava & 56,00 & 31,53 & 55,00 & 23.47 \\
PP-3 & Baixa da Preguiça & 38,00 & 7,73 & 37,00 & 20.27 \\
PZ-5 & Baixa da Preguiça & 34,00 & 7,61 & - & - \\
PZ-6 & Cana-Brava & 73,00 & 60,00 & 72,00 & 12,00 \\
PZ-7 & Aracati & 50,00 & $5 e c 0$ & 49,00 & 0 \\
PZ-9 & Santo Antônio & 50,00 & seco & 49,00 & 0 \\
PP-4 & Faz. Mariazinha & 79,00 & 26,20 & 79,00 & 39,00 \\
PZ-10 & Faz. Mariazinha & 72,00 & 26,10 & - & - \\
PP-5 & ITOGRASS & 71,00 & 13,42 & 68,00 & 38,00 \\
PZ-8 & ITOGRASS & 71,00 & 12,95 & 70,00 & 36,00 \\
\hline
\end{tabular}


A figura 4 apresenta o perfil hidrogeológico AA' longitudinal ao rio Boqueirão, realizado a partir da correlação de perfis de poços, no qual se pode visualizar a ocorrência de falhas geológicas normais inferidas, dispostas de forma escalonada na direção SW-NE. Estas estruturas podem estar influenciando na distribuição, características dimensionais e hidrodinâmicas do Aqüífero Barreiras. Neste sentido, os possíveis falhamentos escalonados para nordeste, estariam favorecendo para a ocorrência de maiores espessuras dos sedimentos do Aqǘf́ero Barreiras e melhor condicionamento hidrogeológico no sentido de montante para jusante da bacia.

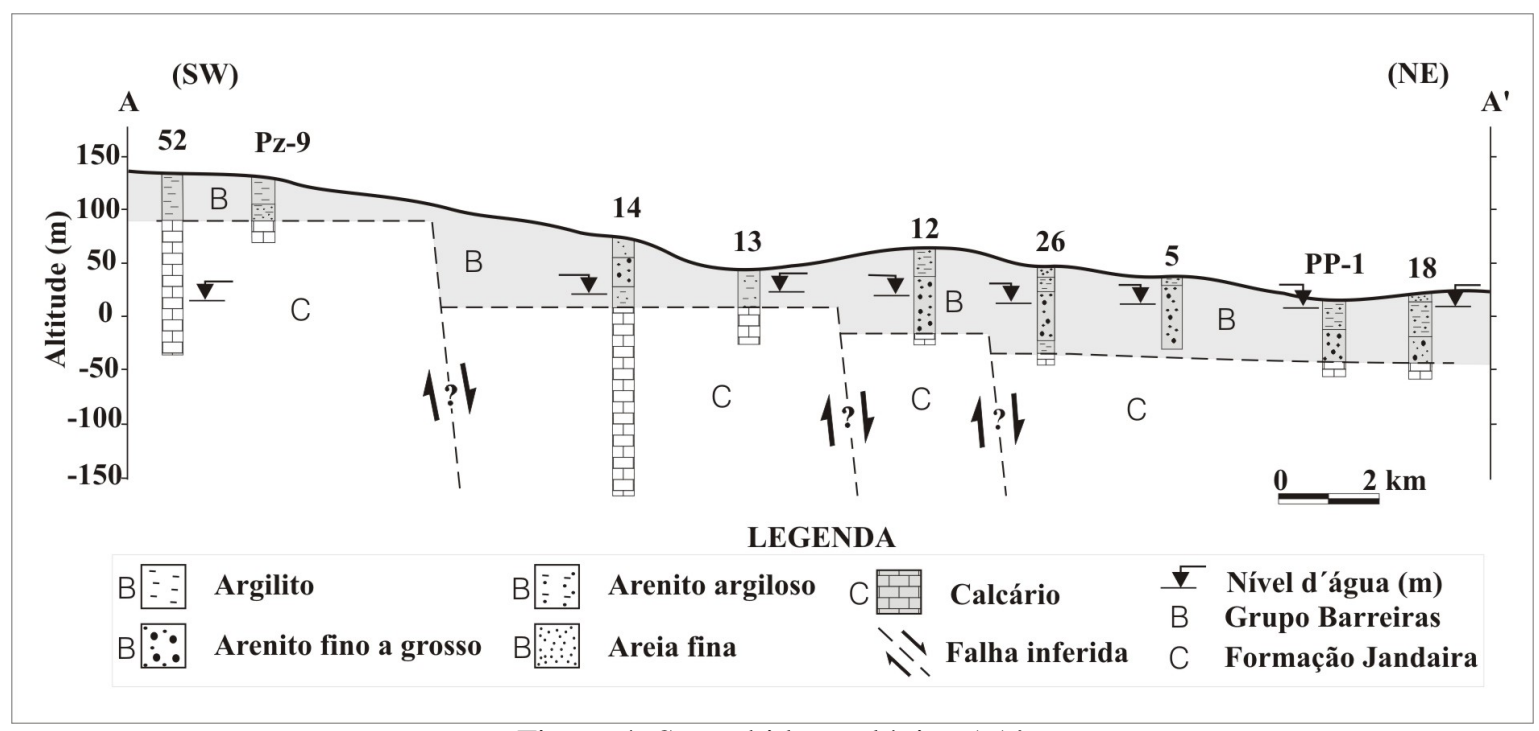

Figura 4: Seção hidrogeológica AA'

Figure 4: Hydrogeological section AA'

Parâmetros hidrodinâmicos do aqüífero Barreiras

O Aqǘfero Barreiras comporta-se em geral como um sistema livre, com ocorrência de semiconfinamentos localizados. Seus parâmetros hidrodinâmicos são apresentados principalmente com base na interpretação dos resultados de cinco testes de aqüífero com utilização de poço(s) de observação. O sítio de cada teste foi localizado considerando os aspectos geológicos e estruturais envolvidos, de modo a se obter informação em diferentes contextos hidrogeológicos (Figura 5).

Os poços testados são totalmente penetrantes no Aqǘf́fero Barreiras, com profundidades variando de 38 a $71 \mathrm{~m}$ (Tabela 2). Foram bombeados com descargas que variaram de 1,9 (PP-3) a 83,7 (PP-1) $\mathrm{m}^{3} / \mathrm{h}$ e os abaixamentos dos níveis da água foram observados em piezômetros situados a distâncias que variaram de $18,5(\mathrm{Pz}-$ 2) a $20,7 \mathrm{~m}(\mathrm{Pz}-8)$.

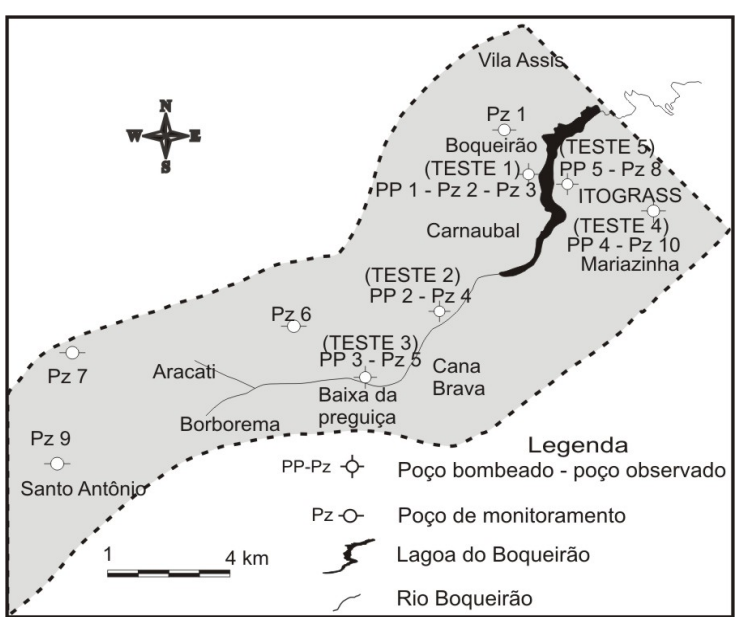

Figura 5-Localização dos testes de aquífero e piezômetros de monitoramento Figure 5- Aquifer tests and piezometers location 
Tabela 2-Resumo dos resultados dos testes de aqüífero

Table 2 - Aquifer tests results

\begin{tabular}{|c|c|c|c|c|c|c|c|c|c|}
\hline \multirow{2}{*}{ Teste } & \multicolumn{2}{|c|}{ Poço } & \multirow{2}{*}{ Prof. } & \multirow{2}{*}{$\begin{array}{l}\text { Tb } \\
\text { (h) }\end{array}$} & \multirow{2}{*}{$\begin{array}{c}\mathbf{r} \\
(\mathbf{m})\end{array}$} & \multirow{2}{*}{$\begin{array}{l}\mathbf{N E} \\
(\mathbf{m})\end{array}$} & \multirow{2}{*}{$\begin{array}{l}\text { ND } \\
\text { (m) }\end{array}$} & \multirow{2}{*}{$\begin{array}{l}\mathbf{s} \\
(\mathbf{m})\end{array}$} & \multirow{2}{*}{$\underset{\left(\mathbf{m}^{3} / \mathbf{h}\right)}{\mathbf{Q}}$} \\
\hline & Bomb & Observ & & & & & & & \\
\hline \multirow[t]{3}{*}{1} & PP-1 & & 58 & 24 & & 1,07 & 12,8 & 11,7 & 83,7 \\
\hline & & PZ-2 & 55 & & 18,5 & 0,63 & 2,2 & 1,6 & \\
\hline & & PZ-3 & 17 & & 20,2 & 0,78 & 1,2 & 0,4 & \\
\hline \multirow[t]{2}{*}{2} & PP-2 & & 62 & 24 & & 32,42 & 39,5 & 7,1 & 36,0 \\
\hline & & PZ-4 & 56 & & 20.2 & 31,53 & 32,3 & 0,8 & \\
\hline \multirow[t]{2}{*}{3} & PP-3 & & 38 & 24 & & 7,73 & 14,5 & 6,7 & 1,9 \\
\hline & & PZ-5 & 34 & & 20,0 & 7,61 & 8,42 & 0,8 & \\
\hline \multirow{2}{*}{4} & PP-4 & & 79 & 24 & & 26,20 & 33,4 & 7,2 & 50,7 \\
\hline & & PZ-10 & 72 & & 19.4 & 26,01 & 27,0 & 1,0 & \\
\hline \multirow[t]{2}{*}{5} & PP-5 & & 71 & 24 & & 12,95 & 18,5 & 5,0 & 73,5 \\
\hline & & PZ-8 & 71 & & 20.7 & 12,95 & 14,5 & 1,6 & \\
\hline
\end{tabular}

Obs.: Prof.: profundidade; Tb: tempo de bombeamento; r: distância do poço bombeado ao poço observado; NE: nível estático; nível dinâmico; s: rebaixamento; Q: vazão

$\mathrm{Na}$ porção mais inferior da bacia hidrográfica, a partir da localidade de Cana Brava, a transmissividade do aqǘf́ero é em média de $4,9 \times 10^{-3} \mathrm{~m}^{2} / \mathrm{s}$ ou $423,4 \mathrm{~m}^{2} /$ dia e a condutividade hidráulica média é de $1,4 \times 10^{-4} \mathrm{~m} / \mathrm{s}$ ou $12 \mathrm{~m} /$ dia. Em direção a montante, as transmisividades do aquífero diminuem, tornando-se nulas no alto curso da bacia, onde os sedimentos Barreiras mostram-se insaturados em toda a sua extensão. Os testes de aqüífero não permitiram uma avaliação da porosidade específica. É possível que o tempo de bombeamento em cada ensaio ( $24 \mathrm{~h}$ ) não tenha sido suficiente para a caracterização da drenagem retardada, fenômeno típico de aquíf́eros livres.

Tabela 3 - Parâmetros hidrodinâmicos do Aquífero Barreiras

Table 3-Barreiras Aquifer hydrodinamic data

\begin{tabular}{|c|c|c|c|c|c|c|c|c|c|}
\hline \multirow[t]{2}{*}{ Teste } & \multicolumn{2}{|c|}{ Poço } & \multirow[t]{2}{*}{$\mathbf{r}(\mathbf{m})$} & \multirow{2}{*}{$\begin{array}{l}\text { Método de } \\
\text { análise }\end{array}$} & \multirow{2}{*}{$\begin{array}{c}\mathbf{T} \\
\left(\mathrm{m}^{2} / \mathrm{s}\right)\end{array}$} & \multirow{2}{*}{$\begin{array}{c}\mathbf{K} \\
(\mathbf{m} / \mathbf{s})\end{array}$} & \multirow{2}{*}{$\begin{array}{c}\mathbf{K}^{\prime} \\
(\mathrm{m} / \mathrm{s})\end{array}$} & \multirow[t]{2}{*}{$\mathbf{S}$} & \multirow[t]{2}{*}{ sy } \\
\hline & Bomb. & Observ. & & & & & & & \\
\hline \multirow[t]{3}{*}{1} & PP-1 & & & & & & & & \\
\hline & & $\mathrm{Pz}-2$ & 18,5 & Hantush & $5,5 \times 10^{-3}$ & $1,8 \times 10^{-4}$ & $1,6 \times 10^{-5}$ & $2,0 \times 10^{-4}$ & \\
\hline & & & & Jacob & $6,3 \times 10^{-3}$ & $2,2 \times 10^{-4}$ & & $2,3 \times 10^{-4}$ & \\
\hline \multirow[t]{3}{*}{2} & PP-2 & & & & & & & & \\
\hline & & $\mathrm{Pz}-4$ & 20,3 & Newman & $3,3 \times 10^{-3}$ & $1,1 \times 10^{-4}$ & & $5,2 \times 10^{-4}$ & $3,5 \times 10^{-2}$ \\
\hline & & & & Jacob & $5,2 \times 10^{-3}$ & $1,7 \times 10^{-4}$ & & $5,9 \times 10^{-5}$ & \\
\hline \multirow[t]{3}{*}{3} & PP-3 & & & & & & & & \\
\hline & & Pz-5 & 20,0 & Newman & $2,0 \times 10^{-4}$ & $1,0 \times 10^{-5}$ & & $1,5 \times 10^{-5}$ & $2,7 \times 10^{-3}$ \\
\hline & & & & Jacob & $4,0 \times 10^{-4}$ & $2,3 \times 10^{-5}$ & & $1,9 \times 10^{-3}$ & \\
\hline \multirow[t]{2}{*}{4} & PP-4 & & & & & & & & \\
\hline & & Pz-10 & 19,4 & Hantush & $5,6 \times 10^{-3}$ & $1,4 \times 10^{-4}$ & & $1,0 \times 10^{-4}$ & \\
\hline \multirow[t]{3}{*}{5} & PP-5 & & & & & & & & \\
\hline & & $\mathrm{Pz}-8$ & 20,7 & Hantush & $5,1 \times 10^{-3}$ & $1,4 \times 10^{-4}$ & & $4,7 \times 10^{-4}$ & \\
\hline & & & & Jacob & $7,6 \times 10^{-3}$ & $2,0 \times 10^{-4}$ & & & \\
\hline
\end{tabular}

Observações: PP: poço bombeado; Pz: piezômetro observado; r: distância entre PP e Pz;

T: transmissividade ; K: condutividade hidráulica do aquífero; K': condutividade hidráulica do aquitard; S: coeficiente de armazenamento; $\mathrm{s}_{\mathrm{y}}$ : porosidade efetiva. 
Fluxo subterrâneo e sua relação com as águas superficiais

A configuração das equipotenciais (Figura 06) indica que existe estreita relação entre as águas subterrâneas e as águas superficiais. A lagoa do Boqueirão é alimentada, em parte, pelas águas subterrâneas oriundas de duas frentes de escoamento bem definidas: uma frente de escoamento do setor sul - sudoeste da lagoa e uma outra oriunda da região a leste deste corpo de água superficial. A lagoa do Boqueirão é também alimentada pelo rio Boqueirão, conhecido localmente como riacho Cana Brava. A vazão do fluxo subterrâneo natural (Q) em direção à lagoa do Boqueirão foi avaliada a partir da lei de Darcy, conforme a seguir indicado:

$$
\mathrm{Q}=\mathrm{TIL}
$$

onde $\mathrm{T}$ é a transmissividade do aquífero $\left(\mathrm{m}^{2} / \mathrm{s}\right)$; I é o gradiente hidráulico e L é a frente de escoamento. A aplicação, tomando por base a Figura 6 e parâmetros hidrodinâmicos médios (obtidos da Tabela 3), resultou em uma descarga de $0,216 \mathrm{~m}^{3} / \mathrm{s}$ em direção a lagoa. De forma similar, a descarga do fluxo subterrâneo saindo da lagoa na direção noroeste, foi avaliada em $0,107 \mathrm{~m}^{3} / \mathrm{s}$. É possível que esta diferença $(0,109$ $\mathrm{m}^{3} / \mathrm{s}$ ) represente a contribuição de água subterrânea para a lagoa do Boqueirão. A vazão total do fluxo subterrâneo natural na área é da ordem de $0,274 \mathrm{~m}^{3} / \mathrm{s}$, desde que $0.058 \mathrm{~m}^{3} / \mathrm{s}$

corresponde a parcela do fluxo subterrâneo no setor oeste dirigido para norte que não é influenciado pela lagoa.

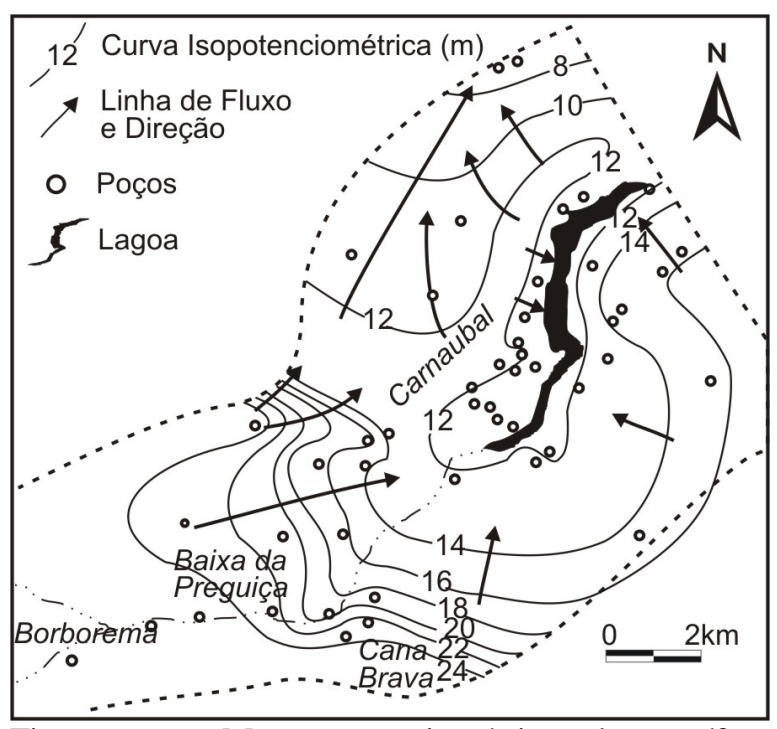

Figura 6 - Mapa potenciométrico do aqüífero Barreiras na bacia do rio Boqueirão-RN.

Figure 6 - Barreiras aquifer potentiometric map (Boqueirão river basin, $-R N)$.

\section{Recarga das águas subterrâneas}

A recarga das águas subterrâneas constitui um parâmetro de fundamental importância no conhecimento e manejo adequado dos aqüíferos (LERNER et al. 1990; FETTTER,1994; SIMMERS et al. 1997; LERNER,1997; HEALY; COOK ,2002; SANFORD, 2002 e VRIES; SIMMERS, 2002). Neste sentido, não se pode explotar e garantir o uso sustentável de um aqüífero ou reserva de águas subterrâneas sem o conhecimento dos mecanismos e volume da recarga anual a que o mesmo é submetido.

As potencialidades do Aquífero Barreiras estão condicionadas principalmente às infiltrações diretas das águas de chuva, cujo volume efetivamente infiltrado restituem as reservas de águas subterrâneas que se perdem nos escoamentos naturais e explotação por poços e, também, alimentam o fluxo subterrâneo. Por definição, em condições de equilíbrio, sem considerar a explotação por poços, a infiltração eficaz é equivalente a vazão do fluxo subterrâneo natural.

A vazão total do fluxo subterrâneo natural foi avaliada em $0,274 \mathrm{~m}^{3} / \mathrm{s}$, o que equivale a aproximadamente 8,6 milhões de $\mathrm{m}^{3} /$ ano. De acordo com o cadastro dos usuários das águas subterrâneas, os recursos explotados anualmente do Aqüífero Barreiras são da ordem de 2 milhões de $\mathrm{m}^{3}$, assim sendo o volume de água efetivamente infiltrado anualmente no terreno é de 10,6 milhões de $\mathrm{m}^{3}$ /ano.

Quanto aos recursos anuais renováveis, tomando-se por base a flutuação sazonal de 1,3 $\mathrm{m}$, obtida do monitoramento mensal dos níveis da água, e, porosidade específica de $7 \%$ (SANTOS, 1982), numa área efetiva de $90 \mathrm{~km}^{2}$ (correspondente ao curso médio da bacia hidrográfica do rio Boqueirão e identificada como a zona produtora), obtém-se para o aqüífero Barreiras uma reserva de 8,2 milhões de $\mathrm{m}^{3} /$ ano. Os estudos regionais indicam uma flutuação média anual do nível potenciométrico do aquífero Barreiras da ordem de 1,62 m. Assim sendo, os recursos anuais renováveis seriam da ordem de 10,2 milhões de $\mathrm{m}^{3} /$ ano. Também, neste estudo regional (SANTOS, 1982), são feitas estimativas da taxa de recarga no aqüífero Barreiras utilizando-se métodos isotópicos (injeção de água tritiada) cujo valor médio obtido foi de $16 \%$. Tomando-se por base este parâmetro, desde que as precipitações (pluviométricas são da ordem de 792 mm/ano, o volume de água infiltrado anualmente na bacia do Boqueirão é da ordem de 11,0 milhões de $\mathrm{m}^{3}$. 
Diante destes resultados, considera-se que a recarga de 10,6 milhões de $\mathrm{m}^{3}$ obtida através da lei de Darcy é um valor aceitável para o Aqüífero Barreiras na área de estudo.

Potencialidades e condições de explotação das águas subterrâneas do aqüífero Barreiras

A bacia do rio Boqueirão apresenta setores com diferentes comportamentos hidrogeológicos condicionados pela presença de falhamentos que limitam a ocorrência e distribuição das águas subterrâneas. A análise integrada dos resultados permitiu a identificação de quatro zonas com diferentes possibilidades em termos de produção de água, conforme apresentado na Figura 07:

Zona (A): Corresponde ao trecho da bacia na altura da lagoa do Boqueirão, onde o Aqüífero Barreiras é de maior potencial hidrogeológico. Neste domínio, o aqǘf́ero apresenta maiores espessuras saturadas e transmissividades mais elevadas. É possível a perfuração de poços produzindo até $100 \mathrm{~m}^{3} / \mathrm{h}$;

Zona (B): É uma estreita faixa da bacia na altura de Cana Brava, cuja potencialidade é referida como média. A produtividade de poços neste domínio é de até $50 \mathrm{~m}^{3} / \mathrm{h}$;

Zona (C ): Envolve as localidades de Borborema e Baixa da Preguiça. Trata-se de uma região bastante afetada por falhamentos que condicionaram a ocorrência de perfis muito argilosos e baixas espessuras saturadas. É de potencial hidrogeológico baixo a muito baixo. Neste setor, é possível a perfuração de poços produzindo no máximo $10 \mathrm{~m}^{3} / \mathrm{h}$.

Zona (D): Corresponde ao curso superior da bacia, onde a estrutura hidrogeológica não contribui para o armazenamento de água subterrânea. As potencialidades do aqüífero neste setor foram identificadas muitíssimo baixas

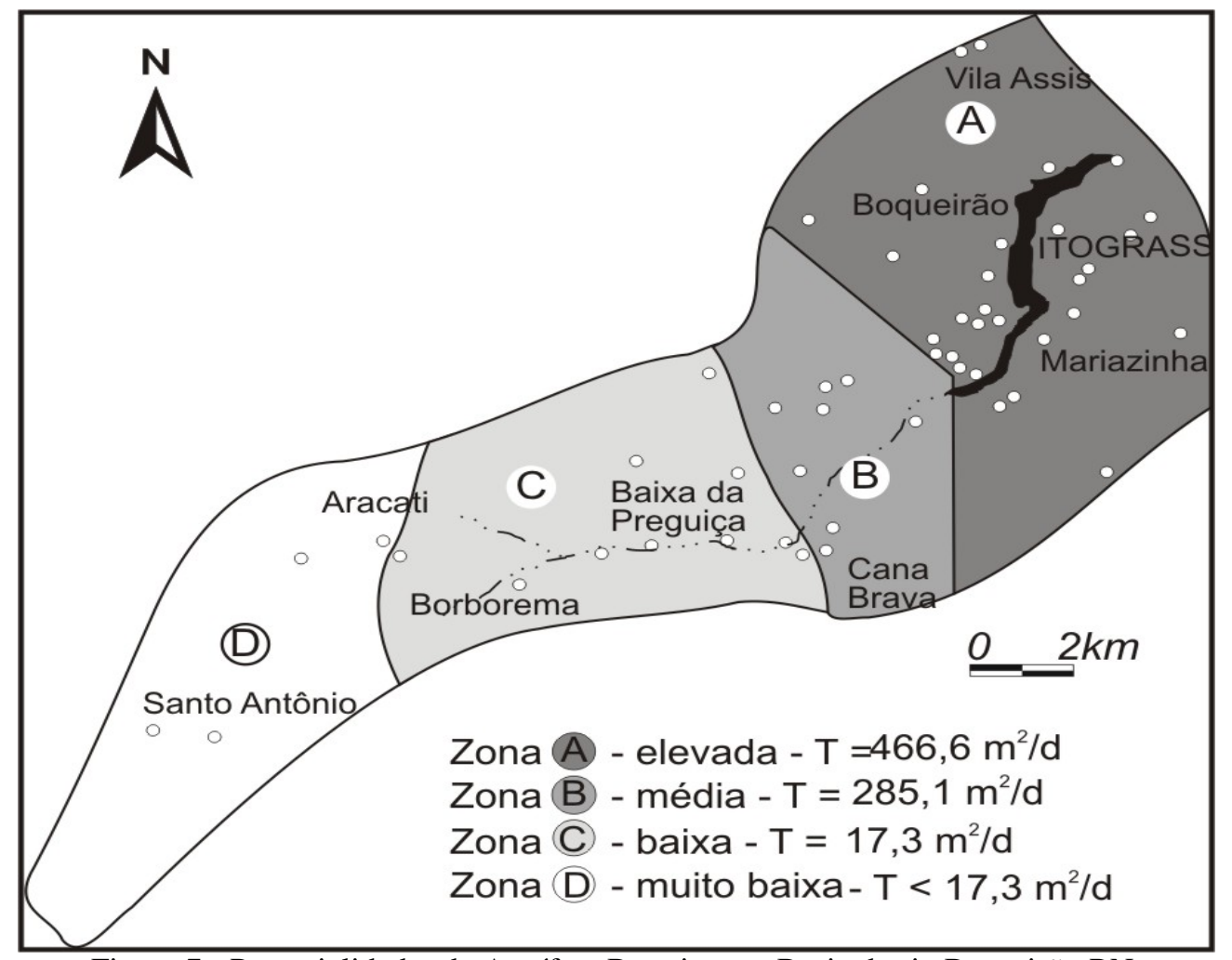

Figura 7 - Potencialidades do Aqüífero Barreiras na Bacia do rio Boqueirão-RN.

Figure 7 - Barreiras Aquifer groundwater availability (Boqueirão river basin , RN).

\section{RECURSOS HÍDRICOS SUPERFICIAIS}

\section{Uso das águas superficiais}

Foram cadastrados 48 usuários da lagoa do Boqueirão, que no seu conjunto exploram um volume total de 7,2 milhões de $\mathrm{m}^{3}$ de água por ano. As águas bombeadas são utilizadas quase que exclusivamente para a irrigação de culturas, de natureza diversa. O setor sul ou margem direita da lagoa é caracterizado por grandes irrigantes e o setor norte, margem esquerda, é dominada por pequenos irrigantes.

\section{Batimetria da lagoa do Boqueirão}

Para o desenvolvimento das simulações necessárias à avaliação das condições de explotação da lagoa do Boqueirão foi necessário a estimativa do volume de acumulação da lagoa, cuja capacidade era desconhecida até $\mathbf{o}$ momento. O levantamento do volume da lagoa foi realizado através de batimetria digital, utilizando-se de um par de GPS (Global Positioning System) de precisão, uma sonda batimétrica, e um microcomputador portátil, cuja 
interpretação dos resultados permitiu estimar os seguintes parâmetros para a lagoa: volume de acumulação: 11,1 milhões de $\mathrm{m}^{3}$; área superficial da lagoa: $2,1 \mathrm{~km}^{2}$; profundidade média: $5,3 \mathrm{~m}$; profundidade máxima: $10,2 \mathrm{~m}$; profundidade mínima: 0,7 m.

\section{Simulação da explotação da Lagoa do Boqueirão}

Para a simulação do comportamento da lagoa do Boqueirão sob diferentes taxas de bombeamento, foi desenvolvido um modelo matemático de simulação hidrológica com período de tempo mensal. $\mathrm{O}$ modelo desenvolvido baseia-se na equação de balanço hídrico e considera as principais variáveis de entrada (I) e saída (O) do sistema, conforme a seguir:

$$
\mathrm{dS} / \mathrm{dt}=\mathrm{I}-\mathrm{O} \text { e dS } \mathrm{S}_{\mathrm{i}}=\mathrm{Q}_{\mathrm{i}}+\mathrm{P}_{\mathrm{i}}-\mathrm{E}_{\mathrm{i}}-\mathrm{D}_{\mathrm{i}}-\mathrm{V}_{\mathrm{i}},
$$

sendo dS a variação de volume na lagoa; $\mathrm{Q}_{\mathrm{i}} \mathrm{o}$ volume afluente; $\mathrm{P}_{\mathrm{i}}$ o volume precipitado diretamente sobre a lagoa; $\mathrm{E}_{\mathrm{i}} \mathrm{o}$ volume evaporado; $D_{i}$ o volume retirado e $V_{i}$ o volume vertido no mês i. O volume mensal afluente à lagoa foi obtido a partir da vazão média mensal de 54 anos, gerada a partir de um modelo chuvavazão (SSARR). Os dados foram obtidos a partir dos estudos desenvolvidos para o Plano Estadual de Recursos Hídricos elaborado para a SERHID, RN (1998).

$\mathrm{O}$ armazenamento da lagoa no mês $\mathrm{i}\left(\mathrm{S}_{\mathrm{i}}\right)$, foi calculado aplicando o balanço hídrico sucessivamente ao longo dos meses de simulação, a partir de um valor inicial dado no início do processo. Verificou-se a possibilidade de explotar uma descarga de $240 \mathrm{~L} / \mathrm{s}$ ou 7,2 milhões de $\mathrm{m}^{3} / \mathrm{ano}$, com uma garantia de $100 \%$ e abaixamentos do nível da lagoa da ordem de 2,00 m.

\section{AVALIAÇÃO HIDROGEOQUÍMICA E QUALIDADE DAS ÁGUAS}

Amostragem, parâmetros e balanço de massas

Estes estudos foram conduzidos com base na interpretação dos resultados de análises químicas de amostras de água coletadas em 21 poços tubulares profundos; 3 poços escavados (cacimbões); 3 piezômetros; 2 pontos da lagoa do Boqueirão e um ponto de água no Rio Boqueirão à montante da lagoa (Figura 08). As coletas foram feitas em fevereiro e março de 2001. As análises foram efetuadas no Laboratório de Análises de Águas e Solos da Empresa de Pesquisa Agropecuária do Rio Grande do Norte (EMPARN) com a determinação dos cátions e ânions principais, além de condutividade elétrica, $\mathrm{pH}$, sólidos totais dissolvidos, alcalinidade, dureza, ferro e os compostos da série nitrogenada: amônia, nitrito e nitrato (Tabela 4). Os teores de nitrito e carbonato não foram detectados, motivo pelo quais os mesmos não foram incluídos na tabela 4. Em todos os casos foi elaborado o balanço de massas o qual indicou uma diferença percentual entre cátions e ânions variando de 0,1 a 3,8\%, o que permitiu caracterizar a boa precisão dos resultados. O erro deve ser inferior a $5 \%$ para uma análise de alta qualidade (PYNE, 1995).

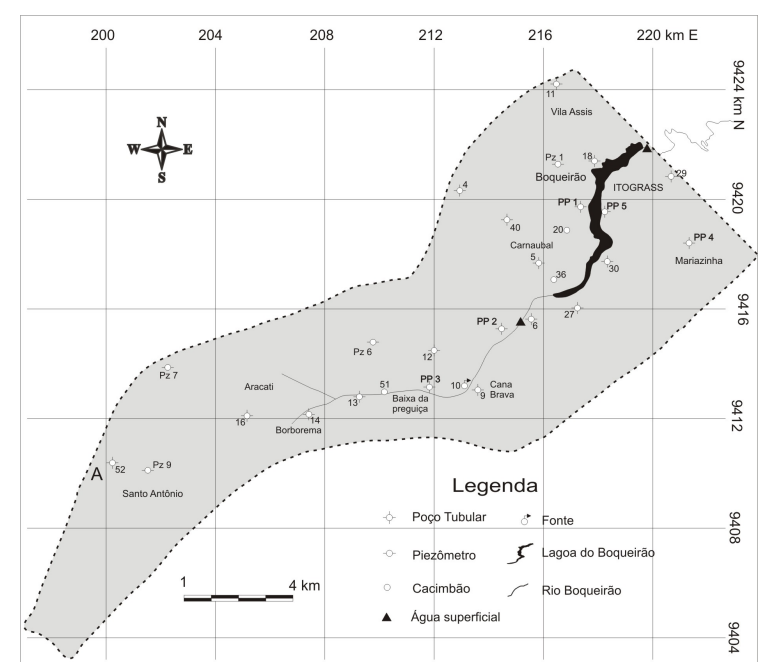

Figura 8 - Localização dos pontos de água amostrados para análise química

Figure 8 - Sampling points for water chemical analysis 
Tabela 4 -Resultados das análises químicas das amostras de água

Table 4 - Water chemical analysis data

\begin{tabular}{|c|c|c|c|c|c|c|c|c|c|c|c|c|c|}
\hline \multirow{2}{*}{ Ponto } & \multirow{2}{*}{ pH } & \multirow{2}{*}{$\begin{array}{c}\mathbf{C E} \\
\mu \mathbf{S} / \mathbf{c m}\end{array}$} & \multirow{2}{*}{$\begin{array}{l}\text { STD } \\
\mathrm{mg} / \mathrm{L}\end{array}$} & \multirow{2}{*}{$\begin{array}{c}\mathrm{NO}_{3} \\
\mathrm{mg} / \mathrm{L}-\mathrm{N}\end{array}$} & $\mathbf{N H}_{3}$ & $\mathbf{C a}$ & Mg & $\mathbf{N a}$ & $\mathbf{K}$ & $\mathbf{F e}$ & $\mathrm{HCO}_{3}$ & $\mathrm{SO}_{4}$ & $\mathrm{Cl}$ \\
\hline & & & & & \multicolumn{9}{|c|}{$\mathrm{mg} / \mathrm{L}$} \\
\hline P-01 & 7,0 & 682 & 464,4 & 0,48 & 0,00 & 11,28 & 14,18 & 95,00 & 13 & 0,1 & 33,9 & 32,82 & 168,97 \\
\hline P-04 & 7,9 & 572 & 389,3 & 0,19 & 0,24 & 8,23 & 20,90 & 49,23 & 13,5 & 0,09 & 94,4 & 15,32 & 29,21 \\
\hline P-05 & 7,2 & 1265 & 949,1 & 0,76 & 0,00 & 39,33 & 74,28 & 108,5 & 34,1 & 0,08 & 7,08 & 84,14 & 392,21 \\
\hline P-06 &, 3 & 154 & 105,2 & 0,95 & 0,00 & 1,32 & 2,89 & 19,36 & 6,66 & 0,04 & 9,75 & 1,37 & 38,45 \\
\hline P-09 & 7.6 & 158 & 107,9 & 0,14 & 0,00 & 11,28 & 7,02 & 9,05 & 7,31 & 0,05 & 64,4 & 2,27 & 21,54 \\
\hline P-12 & 7,4 & 883 & 601,0 & 0,75 & 0,00 & 55,45 & 40,22 & 68,09 & 22,3 & 0,04 & 83,3 & 16,75 & 266,12 \\
\hline P-13 & 0 & 552 & 376,8 & 0,43 & 0,00 & 29,83 & 19,08 & 52,72 & 11,5 & 0,30 & 96,9 & 4,59 & 132,52 \\
\hline P-14 & 7,4 & 1245 & 1052 & 0,00 & 0,00 & 118,3 & 43,25 & 114,0 & 20,7 & 2,90 & 279 & 120,45 & 261,2 \\
\hline P-16 & 7,9 & 532 & 362 & 0,23 & 0,00 & 38,51 & 21,5 & 30,0 & 10,5 & 0,04 & 106 & 4,08 & 119,27 \\
\hline P-18 & 6.8 & 120 & 81,94 & 0,14 & 0,00 & 2,82 & 3,42 & 10,25 & 11,8 & 0,04 & 21,5 & 3,22 & 27,05 \\
\hline C-20 & ,0 & 1486 & 115 & 19,4 & 0,48 & 5,64 & 12,72 & 290,6 & 24,7 & 0,12 & 0,00 & 1,81 & 400,88 \\
\hline P-27 & 6 , & 78 & 24 & 0,15 & 0,00 & 1,0 & 1,10 & 9,8 & 10,5 & 0,43 & 7,31 & 0,06 & 25,14 \\
\hline P-29 & 5 , & 52 & 35,5 & 0,83 & 0,07 & 1,5 & 0,83 & 8,51 & 1,36 & 0,08 & 2,32 & 2,69 & 15,13 \\
\hline P-30 & 5,3 & 46 & 31,76 & 1,17 & 0,00 & 0,99 & 1,21 & 9,54 & 0,55 & 0,04 & 1,87 & 0,73 & 17,25 \\
\hline C-36 & 7,1 & 1546 & 1160 & 9,02 & 0,18 & 8,06 & 9,78 & 296,9 & 27,9 & 0,08 & 45,3 & 65,79 & 434,02 \\
\hline P-43 & 7,4 & 22 & 3 & 0 & 0,55 & 1,61 & 3,79 & 11,54 & 7,22 & 0,10 & 18,0 & 1,0 & 29,12 \\
\hline C-51 & 7,0 & 06 & 12 & 83 & 0,32 & 24,19 & 22,01 & 290,4 & 52,3 & 0,12 & 40,4 & 95,23 & 474,25 \\
\hline P-52 & 8,1 & 1586 & 90 & 2,66 & 0,22 & 139,1 & 88,05 & 90,63 & 8,45 & 0,10 & 209 & 67,23 & 479,23 \\
\hline PP-01 & 6,6 & 1185 & 75,8 & 0,87 & 0,09 & 90,72 & 50,14 & 69,09 & 16,0 & 0,22 & 35,7 & 17,86 & 364,44 \\
\hline PP-02 & 7,9 & 903 & 54,8 & 0,36 & 0,15 & 48,38 & 28,12 & 100 & 9.09 & 0,00 & 86,1 & 20,26 & 252,49 \\
\hline PP-03 & 6 & 401 & 267,6 & & 1 & 2,42 & 3,42 & 72,72 & 12,3 & 0 , & 11,1 & 27,78 & 107,22 \\
\hline PP-04 & 5 , & 65 & & 0,00 & 0,2 & 1,21 & 0,98 & 8,46 & 2,78 & 0,13 & 3,94 & 0,00 & 19,88 \\
\hline PP-05 & 6,0 & 60 & 6 & 0,00 & 0,5 & 2,42 & 0,24 & 6,92 & 5,71 & 0,13 & 10,1 & 0,00 & 16,56 \\
\hline PZ-01 & 7,6 & 532 & 295,6 & 0,14 & 0,26 & 35,48 & 24,45 & 32,5 & 10,8 & 0,08 & 90,6 & 19,86 & 112,64 \\
\hline PZ-02 & 7,8 & 823 & 515,4 & 0,00 & 1.29 & 67,74 & 22,5 & 70,91 & 12,7 & 0,08 & 82,0 & 14,62 & 238,54 \\
\hline PZ-03 & 6,6 & 487 & 291,8 & 0,78 & 0,46 & 38,29 & 20,54 & 28,75 & 11,9 & 0,00 & 47,5 & 7,98 & 135,84 \\
\hline F-10 & 7,2 & 190 & 134,4 & 0,00 & 0,12 & 9,27 & 2,2 & 20,5 & 8,33 & 0,07 & 29,6 & 7,19 & 38,1 \\
\hline LM & $8,($ & 431 & 271,6 & 0,19 & 0,14 & 25,61 & 10,63 & 48,03 & 7,44 & 0,09 & 75,8 & 14,45 & 97,03 \\
\hline LJ & 7,9 & 426 & 284,8 & 0,01 & 0,61 & 19,76 & 10,57 & 50,72 & 8,45 & 0,10 & 55,0 & 16,05 & 100,26 \\
\hline RM & 7,7 & 376 & 256,1 & 0,00 & 0,24 & 21,77 & 11,98 & 35,0 & 6,66 & 0,29 & 71,9 & 22,75 & 71,23 \\
\hline
\end{tabular}

Observações: P: poço tubular; Pz: piezômetro; C: cacimbão; PP: poço tubular testado; F: fonte; LM: montante da lagoa; LJ: jusante da lagoa; RM: rio montante da lagoa.

\section{Análise hidrogeoquímica}

No domínio da bacia hidrográfica do Boqueirão ocorrem setores com diferentes características hidroquímicas, os quais serão a seguir discutidos.

No setor a leste da lagoa do Boqueirão, as águas subterrâneas apresentaram condutividade elétrica variando de 46 a $122 \mu \mathrm{S} / \mathrm{cm}$, com média de $71 \mu \mathrm{S} / \mathrm{cm}$; o teor de cloreto variou de 15,13 a $29,12 \mathrm{mg} / \mathrm{L}$, com média de 20,51 mg/L; o pH variou de um mínimo de 5,30 a um máximo de 7,40, com média de 5,98. Assim sendo, as águas são de salinidade muito baixa e em geral ácidas.

No setor a oeste da lagoa do Boqueirão, as águas subterrâneas apresentam condutividade elétrica variando de 120 a $1546 \mu \mathrm{S} / \mathrm{cm}$, com média de $870 \mu \mathrm{S} / \mathrm{cm}$, portanto, são águas de salinidade bem mais elevada que as águas do setor a leste da lagoa; o cloreto variou de 27,05 a $434,02 \mathrm{mg} / \mathrm{L}$, com média de 240,28 mg/L; quanto ao $\mathrm{pH}$, o valor mínimo foi de 4,00 e o máximo de 7,90 , com média de 6,86 , portanto, em condições similares ao obtido no caso anterior.
No setor a montante da lagoa do Boqueirão, as águas apresentam condutividade elétrica variando de 154 a $1606 \mu \mathrm{S} / \mathrm{cm}$, com média de $746 \mu \mathrm{S} / \mathrm{cm}$. O teor de cloreto variou de 21,52 a $479,23 \mathrm{mg} / \mathrm{L}$, com média de $199,12 \mathrm{mg} / \mathrm{L}$; O pH variou de 6,30 a 8,10, com média de 7,40, mostrando uma certa tendência para águas mais básicas. Em termos de salinidade, estas águas são similares às águas do setor oeste da lagoa.

A elevada salinidade das águas do Aqüífero Barreiras no setor a oeste da lagoa e a montante da mesma esta associado a uma provável contribuição das águas dos calcários subjacentes que regionalmente são de salinidade elevada, podendo também estar sendo influenciada pelo clima do domínio semi-árido da Bacia Potiguar.

As águas superficiais (rio e lagoa) apresentam níveis de salinidade baixa a média, com condutividade elétrica variando de 150 a 500 $\mu \mathrm{S} / \mathrm{cm}$. Observa-se, entretanto, que há um aumento da condutividade de montante para jusante. 
Os resultados das análises químicas dos cátions e ânions principais das amostras de água analisadas, expressos em termos percentuais, são representados no diagrama trilinear de Piper na Figura 09 , no qual podem-se identificar os tipos hidroquímicos dominantes e associá-los com as diferentes direções do fluxo subterrâneo, unidades geológicas e os aspectos estruturais envolvidos.

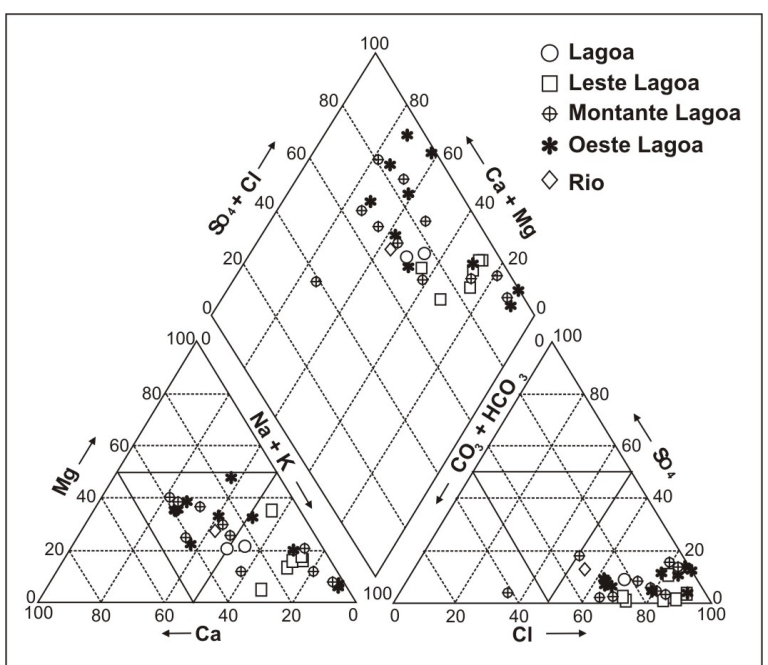

Figura 9-Resultados das análises químicas de água no diagrama de Piper

Figure 9 - Piper diagram displaying the composition of groundwater samples taken from Barreiras Aquifer

As águas do setor a leste da lagoa do Boqueirão, além de serem de salinidade muito baixa, conforme mostrado anteriormente, são, em geral, águas do tipo $\mathrm{Na}^{+}-\mathrm{Cl}^{-}$, que é uma característica das águas do Aqüífero Barreiras, regionalmente ou mais precisamente na maior parte da faixa costeira leste do Estado.

Nos setores a oeste e a montante da lagoa do Boqueirão, as águas do Aqüífero Barreiras tendem a ser do tipo $\mathrm{Ca}^{2+}-\mathrm{Mg}^{2+}-\mathrm{Cl}^{-}-\mathrm{HCO}_{3}$. Estas águas estão, provavelmente, afetadas pelos arenitos calcíferos, calcários e dolomitos subjacentes ao Aqüífero Barreiras, cuja formação geológica aflora a uma distância de cerca de $8 \mathrm{~km}$ da extremidade oeste da área de estudo. Os casos de águas do tipo $\mathrm{Na}^{+}-\mathrm{Cl}^{-}$neste setor, correspondem a águas de poços escavados (cacimbões) sem nenhuma proteção sanitária ou abandonados, provavelmente, afetadas por contaminantes.

As águas do rio e lagoa do Boqueirão, de salinidade baixa a média, são dominadas pelo ânion cloreto seguido do bicarbonato, e, cátion sódio, seguido de cálcio e magnésio ou seja, são águas $\mathrm{Na}^{+}-\mathrm{Ca}^{2+}-\mathrm{Mg}^{2+}-\mathrm{Cl}^{-}-\mathrm{HCO}_{3}^{-}$. Representam uma provável mistura de águas dos arenitos do Aquíífero Barreiras e dos arenitos calcíferos, calcários e dolomitos da Formação Jandaíra, com um maior percentual de águas do Aqüífero Barreiras. As posições dos pontos no diagrama de Piper representando as águas superficiais sugerem este fato.

Associando a distribuição dos pontos de água no triângulo dos cátions (diagrama de Piper) com a situação no terreno, verifica-se que na direção geral leste - oeste do fluxo subterrâneo, o cátion sódio tende a trocar de posição com o cátion cálcio ou magnésio e no triângulo dos ânions, o cloreto tende a ser substituído pelo íon bicarbonato. Isto naturalmente ocorre por influência das rochas carbonáticas, cujas águas em geral são bicarbonatas cálcicas e ou magnesianas. Os processos geoquímicos envolvidos, provavelmente incluem reações de troca iônica e simples mistura.

\section{Qualidade das águas}

$\mathrm{O}$ conceito de qualidade das águas geralmente está associado às características das mesmas quanto à sua utilização. Assim sendo, o conhecimento de suas propriedades físicas, químicas e bacteriológicas são fundamentais. Os aspectos bacteriológicos não são levados em consideração neste trabalho. A qualidade das águas subterrâneas e superficiais da bacia hidrográfica do rio Boqueirão, no domínio estudado, é avaliada levando-se em consideração o uso das mesmas no abastecimento humano e irrigação.

Com relação ao uso das águas subterrâneas no abastecimento humano, a análise dos resultados das amostras permitiu as seguintes considerações: as águas subterrâneas não apresentam restrições com relação aos parâmetros físicos; $70 \%$ das amostras de água analisadas indicam águas de excelente a boa qualidade química para o uso humano e $30 \%$ apresentam concentrações de cloreto superior a $250 \mathrm{mg} / \mathrm{L}$, que é o limite estabelecido pela OMS para uma água potável. Estas águas, com teores elevados de cloreto, apresentam, em alguns casos, sólidos totais dissolvidos elevados e concentrações também elevadas de sódio e ferro. São águas provenientes de poços escavados (cacimbões) sem nenhuma proteção e, portanto, vulneráveis à contaminação. As águas superficiais são, em geral, de boa qualidade físico-química, ressaltando-se, entretanto, que na lagoa do Boqueirão, em ponto de coleta próximo ao limite superior da lagoa, foi constatada a presença de nitrogênio amoniacal com concentração de $0,14 \mathrm{mg} / \mathrm{L}$ e próximo ao seu limite inferior (área utilizada por banhistas), de 
0,61 mg/L, sugerindo feita indícios de contaminação no reservatório superficial.

A qualidade das águas para a irrigação foi caracterizada levando-se em conta o risco de salinidade segundo a condutividade elétrica (CE) e segundo o risco de alcalinização (SAR) conforme apresentado na Tabela 5. O SAR é definido pela relação:

$$
S A R=\frac{r N a}{\sqrt{\frac{(r C a+r M g)}{2}}},
$$

onde $\mathrm{r}$ indica valores em meq/L

Enquanto que altas concentrações de sais na água contribui para a formação de um solo salino, alta concentração de sódio contribui para o desenvolvimento de um solo alcalino. Um solo alcalino tem uma estrutura desfavorável, encharca facilmente e limita a aeração. Além disso, alta saturação em sódio causa deficiência de cálcio.

As águas subterrâneas do Aquíífero Barreiras no setor a leste da lagoa do Boqueirão são "excelentes" para irrigação: o risco de salinidade é baixo, uma vez que a condutividade elétrica registrada variou de 47 a $122 \mu \mathrm{S} / \mathrm{cm}$ a $25^{\circ} \mathrm{C}$. O risco de sódio (alcalinização) é igualmente baixo, cujos valores do SAR foram de 1,1 até 1,5. Nos outros setores da área, as águas subterrâneas foram classificadas em geral como "médias" quanto ao uso na irrigação: A condutividade elétrica, em sua maioria, foi maior que 402 $\mu \mathrm{S} / \mathrm{cm}$ e menor que $1606 \mu \mathrm{S} / \mathrm{cm}$, com valor médio de $808 \mu \mathrm{S} / \mathrm{cm}$; o valor do SAR, em $76 \%$ dos casos, foi menor que 2,28. As águas da lagoa e rio Boqueirão, foram classificadas como "boas" para a irrigação: As amostras coletadas na lagoa apresentaram condutividade elétrica média de $356 \mu \mathrm{S} / \mathrm{cm}$ e o SAR, valor de 2,1 ; as características do rio Boqueirão são similares ao observado para a lagoa, cujos valores da condutividade elétrica e SAR foram $377 \mu \mathrm{S} / \mathrm{cm}$ e 1,5, respectivamente (Tabela 6).

\section{DISCUSSÃO DOS RESULTADOS}

Os diferentes comportamentos do Aquífero Barreiras nos quatros setores da bacia do rio Boqueirão é atribuído ao seguinte: primeiramente, a área está localizada numa zona de transição entre uma região úmida (faixa costeira leste) e uma região semi-árida (Bacia Potiguar) e, por conseguinte, é influenciada pelos dois tipos climáticos; segundo, o caráter geológico e estrutural, tanto local como regional, que favorece diferentes particularidades hidrogeológicas. Esses caracteres, em alguns setores da área, favorecem a distribuição e o armazenamento das águas subterrâneas e, em outros setores, limitam este recurso ou impedem o seu desenvolvimento.

A ocorrência de falhamentos escalonados no sentido de montante para jusante da bacia do Rio Boqueirão contribui para maiores espessuras saturadas e maiores transmissividades do Aquífero Barreiras nesta direção. No curso superior da bacia, os sedimentos Barreiras estão praticamente insaturados e no médio curso esses sedimentos desenvolvem espessuras saturadas de até $47,0 \mathrm{~m}$ e transmissividades da ordem de 423,4 $\mathrm{m}^{2} / \mathrm{d}$.

As condições litoestruturais dominantes do Aquífero Barreiras atribuem a ele, características de um sistema livre com a ocorrência localizada de semiconfinamentos.

Existe estreita relação entre as águas subterrâneas e superficiais. A lagoa do Boqueirão é alimentada pelo rio Boqueirão e pelas águas subterrâneas, além da contribuição do fluxo superficial oriundo dos setores norte e sul da área. A contribuição direta de águas subterrâneas para esse reservatório superficial é da ordem de $0,109 \mathrm{~m}^{3} / \mathrm{s}$. O rio Boqueirão é originado por surgências de águas subterrâneas na parte superior da bacia.

A superfície de cerca de $90 \mathrm{~km}^{2}$, no médio curso da bacia do rio Boqueirão, que envolve as localidades de Cana Brava e Carnaubal, é a área produtora, ou seja, aquela que apresenta melhores condições hidrogeológicas. Em uma primeira aproximação e em caráter potencial, os recursos anuais explotáveis do Aquífero Barreiras serão tomados como equivalentes à recarga anual e, assim sendo, a oferta de água subterrânea poderá vir a ser ampliada em cerca de 8,6 milhões de $\mathrm{m}^{3}$, desde que 2 milhões já são explotados atualmente.

Baseado no modelo de simulação matemática verifica-se ser possível o bombeamento da lagoa do Boqueirão com uma taxa de 7,2 milhões de $\mathrm{m}^{3} /$ ano. Considerando, entretanto, que já é captado da lagoa quase este valor, não se recomenda nenhum bombeamento adicional neste reservatório superficial.

Quanto à qualidade das águas, as águas do setor a leste da lagoa do Boqueirão são de excelente qualidade para o uso humano e irrigação. Neste caso, elas podem ser usadas sem restrições em quase todos os tipos de solos e culturas. As águas dos demais setores, entretanto, apresentam alguma restrição, notadamente pela salinidade média a alta das águas. $O$ uso das águas, neste caso, é recomendado em solos com moderada drenagem e irrigação de culturas com 
moderada resistência aos sais. As águas superficiais (lagoa e rio), em suas condições naturais, são boas para o uso humano, alertandose, entretanto, quanto a presença de nitrogênio amoniacal com teor de $0,61 \mathrm{mg} / \mathrm{L}$ no balneário da lagoa do Boqueirão, o que já pode ser um indicativo de contaminação. Com relação à irrigação, podem ser usadas em quase todos os tipos de solos e em culturas com baixa a moderada resistência aos sais.

Tabela 5-Classificação da água para irrigação (RAGHUNATH, 1982; LLOYD; HEATHCOTE, 1985)

Tabela 5 - Water types and irrigation risks (RAGHUNATH, 1982; LLOYD; HEATHCOTE, 1985)

\begin{tabular}{lcc}
\hline Classe de água & $\begin{array}{c}\text { Risco de salinidade } \\
\left(\mathrm{CE} \mathrm{em} \mu \mathrm{S} / \mathrm{cm} \mathrm{a} 25^{\circ} \mathrm{C}\right)\end{array}$ & $\begin{array}{c}\text { Risco de alcalinização } \\
(\mathrm{SAR})\end{array}$ \\
\hline Excelente & $<250$ & $<10$ \\
Boa & $250-750$ & $10-18$ \\
Média & $750-2250$ & $18-26$ \\
Má & $2250-4000$ & $>26$ \\
Muito má & $>4000$ & \\
\hline
\end{tabular}

Tabela 6 -Tipos de água quanto ao uso na irrigação

Tabela 6 - Barreiras aquifer water categories according to irrigation use

\begin{tabular}{|c|c|c|c|c|c|}
\hline Situação & Amostra & Local & $\mathrm{CE}(\mu \mathrm{S} / \mathrm{cm})$ & SAR & Classe de água \\
\hline Lagoa & $\mathrm{LJ}-55$ & Boqueirão & 426 & 2,29 & Boa \\
\hline Lagoa & LM-54 & Bebida Velha & 284 & 2,01 & Boa \\
\hline Leste da lagoa & P-27 & Faz. Mergulhão & 78 & 1,61 & Excelente \\
\hline Leste da lagoa & P-29 & Faz. Jaf & 52 & 1,38 & Excelente \\
\hline Leste da lagoa & P-30 & Faz. Grauna & 46 & 1,52 & Excelente \\
\hline Leste da lagoa & P-43 & Bebida Velha & 122 & 1,13 & Excelente \\
\hline Leste da lagoa & PP-4 & Mariazinha & 65 & 1,39 & Excelente \\
\hline Leste da lagoa & PP-5 & ITOGRASS & 60 & 1,14 & Excelente \\
\hline Montante lagoa & C-51 & Baixa da Preguiça & 1006 & 10,28 & Média \\
\hline Montante lagoa & F-10 & Cana Brava & 190 & 1,57 & Excelente \\
\hline Montante lagoa & P-12 & Cana Brava & 883 & 1,7 & Média \\
\hline Montante lagoa & P-13 & Baixa da Preguiça & 552 & 1,87 & Boa \\
\hline Montante lagoa & P-14 & Borborema & 1245 & 2,28 & Média \\
\hline Montante lagoa & P-16 & Aracati & 532 & 0,96 & Média \\
\hline Montante lagoa & P-52 & Santo Antônio & 1586 & 1,48 & Média \\
\hline Montante lagoa & P-6 & Boa Cica & 154 & 2,16 & Excelente \\
\hline Montante lagoa & P-9 & Cana Brava & 158 & 0,52 & Excelente \\
\hline Montante lagoa & PP-2 & Cana Brava & 903 & 2,83 & Média \\
\hline Montante lagoa & PP-3 & Baixa da Preguiça & 401 & 7,05 & Boa \\
\hline Oeste lagoa & $\mathrm{C}-20$ & Carnaubal & 1486 & 15,51 & Média \\
\hline Oeste lagoa & C-36 & Carnaubal & 1114 & 16,62 & Média \\
\hline Oeste lagoa & P-1 & Vila Isabel & 682 & 4,42 & Boa \\
\hline Oeste lagoa & P-18 & Boqueirão & 120 & 0,97 & Excelente \\
\hline Oeste lagoa & P-4 & Vila Assis & 572 & 1,71 & Boa \\
\hline Oeste lagoa & P-52 & Carnaubal & 1265 & 2,35 & Média \\
\hline Oeste lagoa & PP-1 & Boqueirão & 1185 & 1,44 & Média \\
\hline Oeste lagoa & PZ-1 & Vila Assis & 532 & 1,03 & Boa \\
\hline Oeste lagoa & PZ-2 & Boqueirão & 823 & 1,91 & Média \\
\hline Oeste lagoa & PZ-3 & Boqueirão & 487 & 0,93 & Boa \\
\hline Rio & $\mathrm{R}-53$ & Boa Cica & 376 & 1,5 & Boa \\
\hline
\end{tabular}




\section{CONCLUSÕES}

Baseado nas considerações apresentadas, o objetivo deste trabalho, de avaliar as possibilidades de aumento da oferta de água para o desenvolvimento da área do Boqueirão e de exportar água para comunidades na região semiárida, foi atingido.

O volume potencial explotável de água subterrânea e superficial na área é de aproximadamente 17,8 milhões $\mathrm{de} \mathrm{m}^{3} / \mathrm{ano}$. Desde que 9,2 milhões de $\mathrm{m}^{3} / \mathrm{ano}$ de água já são retirados destes recursos, há um volume suplementar de água de 8,6 milhões de $\mathrm{m}^{3} / \mathrm{ano}$ que pode ser usado de acordo com as prioridades a serem estabelecidas.
Este volume é representado por água subterrânea, uma vez que nenhum bombeamento adicional é recomendado para a lagoa, cujo volume explotado está no seu limite máximo. Tendo em vista o uso equilibrado dos recursos hídricos na área estudada, recomenda-se continuar o monitoramento do nível das águas subterrâneas e do nível da lagoa do Boqueirão, além da descarga do rio Boqueirão. Igualmente, o monitoramento da qualidade das águas é também recomendado. Esta constitui a estratégia de manejo mais adequada no sentido de controlar a explotação das águas e contribuir com o desenvolvimento sustentável dos recursos hídricos. 


\section{REFERÊNCIAS}

FETTER C.W. Applied Hidrogeology, $3^{\text {rd }}$ ed. Prentice Hall, Uppper Saddle River, New Jersey, 1994.

HEALY R.W.; COOK P.G. Using groundwater levels to estimate recharge. Hydrogeology Journal, 10 (1), 91-109, 2002.

LERNER D.N. Groundwater recharge. Geochemical Processes, Weathering and Groundwater Recharge in Catchments. A.A. Balkema, Rotterdam, Brookfield, 109-150, 1997.

LERNER D.N., ISSAR AS AND SIMMERS I. Groundwater recharge: a Guide to understanding and estimating natural recharge. International. Association of Hydrogeologists, vol 8. Hannover: Heise, 1990.

LLOYD J.W.; HEATHCOTE, J.A. Natural inorganic hydrochemistry in relation to groundwater - in introduction. Okford: Clarendon Press, 1985.

MONT'ALVERN, A. Mapa Geológico do Estado do Rio Grande do Norte. DNPM - Sede - $4^{\circ}$ Distrito/UFRN/PETROBRAS/CRM, 1998.

PYNE, R.D. Groundwater Recharge and wells - A guide to aquifer storage recovery. CRC Press, Inc/ Lewis Publishers, 1995.

RAGHUNATH, H.M. Groundwater. A Halsted Press Book. John Wiley \& Sons, Inc., New York. 1982.
SANTOS, J. P. Estudo Hidrogeológico Regional do Estado do Rio Grande do Norte. Instituto de Pesquisas Tecnológicas do Estado de São Paulo/ Secretaria de Indústria e Comércio do Rio Grande do Norte. (Report 15795 - 9 volume). IPT, São Paulo, 1982.

SIMMERS, I, HENDRICKX, J. M. H., KRUSEMAN, G. P. AND RUSHTON K. R. Recharge of phreatic aquifers in (semi-) arid areas. International Association of Hydrogeologists, 19, A.A. Balkema, Rotterdam, Brookfield, 1997.

SANFORD, W. Recharge and groundwater models: an overview. Hydrogeology Journal, 10 (1), 110120, 2002.

SERHID. Plano Estadual de Recursos Hídricos do Rio Grande do Norte - Recursos hídricos superficiais. Secretaria de Recursos Hídricos do Rio Grande do Norte, Natal, RN, 1998

VRIES, J.J.; SIMMERS, I. Groundwater recharge: an overview of processes and challenges. Hydrogeology Journal, 10 (1), 5-17, 2002. 
Avaliação integrada dos recursos de águas subterrâneas e superficiais da bacia do rio Boqueirão, a oeste de Touros, RN 